\title{
抑うつ状態における間腷一下垂体一副腎 皮質系機能に関する研究
}

\author{
II. 血中 Steroid 像について

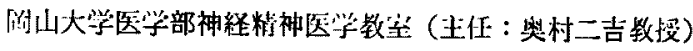 \\ 过治憲
}

[昭和 38 年 4 月 18 日㺼稿]

\section{粕言}

著者は第 1 粨において内因性うつ脑，爻応性うつ

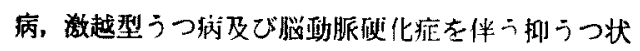
態忠者の，尿中に排泄される 17-Ketosteroids，(17KS と略記する) 17-Hydroxvcorticoids (17-OHCS と略記する）を検相し，対照群の正常值と比洨して 17-KS, 総 17-OHCS 值の低下, 遊㜠型 17.0HCS の增加, 結令型 17-0HCS の減少, それ飞伴う

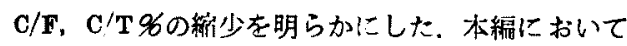
は，末梢血中における 17-OHCS 像の動態を娭查 し，尿中ステロイド像との比较において抑うつ状悲 の閒脳一下垂体一副䦽皮啠系機能在梌㣙したい上 思う。

\section{実鍳方法及ひ材料}

\section{1) 実験材料}

时静脈血約 $30 \mathrm{ml}$ 早朝究腹時 (午前 8 時) : 採取して用いた．対照正常人は18〜21才の䦥山大学 医学部附属青護学院の女子学!決12多之，25 47才の

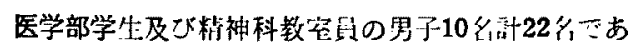
る.これらの刘然羘は拯血前日から特に刺战を咯り， 女子の场合は月経第 1 日目上り数えて利18日乃至牙 23日目目の間に採向することにした。

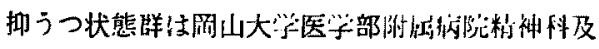

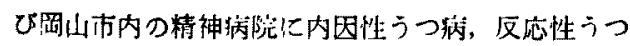

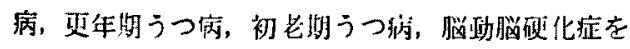
伴ううつ状態等の診断て人院したちのであり，治療 又は投桨考行つていない状悲で俟査したものである.

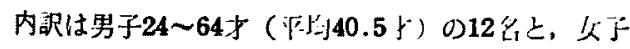

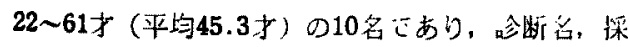
血時主要症状仕表 4 に一括して揭げてある．抑うつ 状䈍群においても女子の埸会は正常群と同漛に月経 周期との閣係を考㤝して採血した。

\section{2）実駼方法}

測定方法は Nelson \& Samuels1)の方法を用い, 絬合型湖定には Bongiovanni の方法910) を応用し た. 大要は次の通りである。

試桼

1. ヘパリン酸ソーダ

2. 95\%エタノール

3. エチル醋酸 $\left(61.2^{\circ} \mathrm{C}\right.$ で再蒸留したもの)

4. $0.1 \mathrm{~N} \cdot \mathrm{NaOH}$

5. 醋酸綵雨液 $(0.2 \mathrm{~mol}$ 水醋酸溶䍇及び $0.2 \mathrm{~mol}$ 醋粉ソーダ溶液)

6. $\beta$-Glucuronidase (Warner-Chilcot 社彆牛肝 $\beta$-Glucurunidase, 力侕5000 Fishman unit $/ \mathrm{ml}$ )

7. クロロフオルム（使用淔前に脱水剂及ひ2 2,4dinitrophenylhydrazine を加え，蒸溜精製する).

8. 無水メタノール

9. 呈色試蒋

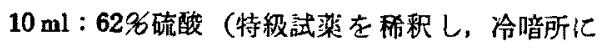
保存)

$6.5 \mathrm{mg}$ : 盃酸フエニールヒドラジン（白色微細針 状絬到上なる迄精㡀したもの)

$3.3 \mathrm{ml}:$ 热水エタノール

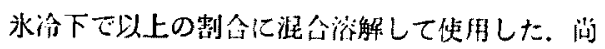

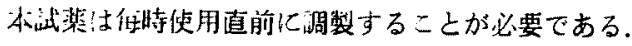
10. 旨検試脽

施酸フエニールヒドラジンを加えず，二の他の紐 成は尘他試愁同梾である。

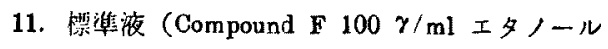

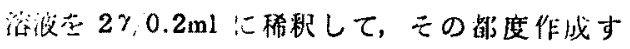
a).

实施

1. ヘパリン酸ソーダ $1 \mathrm{ng}$ 夺加えて标梢血約 30

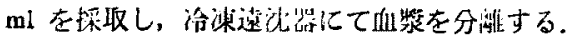


治

2. 血漿 $10 \mathrm{ml}$ とつき $2.5 \mathrm{Vol}(25 \mathrm{ml})$ の $95 \%$ エタノールを加えて光分港拌业，約10分間遠沈し上 清を 1〜2 $\mathrm{ml}$ までに減代乾燥させる。.

3. 上記資料を約 $10 \mathrm{ml}$ の渠溜水比て分液漏斗 中に沙い移し，これをエチル醋酸 $25 \mathrm{ml}$ で 3 回抽 出し，抽出相全部を合わす， $0.1 \mathrm{~N} \cdot \mathrm{NaOH} 10 \mathrm{ml}$ で 2 回，篦雷水 $10 \mathrm{nll}$ て 2 回沇游し，丸底フラスコに移 寸. 呬侩式 quick evaporator を用い約 $40^{\circ} \mathrm{C}\left(47^{\circ} \mathrm{C}\right.$

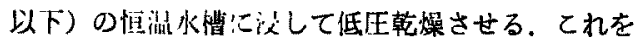
遊離型 17-OHCS 测定用の資料とする。

4. 3で门つたエチール醋酸抽出後の資料を醋酸

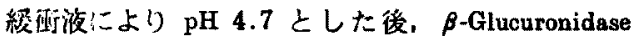
$2 \mathrm{ml}\left(10,000\right.$ Fishman unit) を加えて, $38^{\circ} \mathrm{C}$ の恒 温慒肉に48持诃保温する。

5. 你往したものを取り出し流水で冷动した後， 3 上同栐に操作して絬合型 17-OHOS 测定化供する。

6. 盗料を粘慗するため Florisil カラムに通す。 即ち 3 及び 5 の資料を夫々 $12 \mathrm{ml}$ のクロロフオル 厶を用い6，4，2 ml 㠾 3 回にて完全に溶解し，絇 $7 \mathrm{~cm}$ (直径 $8 \mathrm{~mm}$ )の们き詰めた Florisil カラム に汪ぐ.

7. 次にクロロフオルム $20 \mathrm{ml}$ をカラムに注ぎ, 終了後メタノール2名をむ゙クロロフォルム $25 \mathrm{ml}$ で沁い流し，最後にメタノール25\%を念むクロロフ オルム $45 \mathrm{ml}$ を流下せしめこの分剽を採取する。こ れを窒䋈ガス下义は減任乾燥させる。

8. こ扎 $6 \mathrm{ml}$ のエタノールを加えてよく溶解 させ 2 本の試験管㲸 $2 \mathrm{ml}$ 多分注し，一方の列汇呈色 試沗を，他の列に盲検试浆を夫々 $3 \mathrm{ml}$ 夗加えて上 く混合させ, $60^{\circ} \mathrm{C}, 30$ 分闾保混㙏色後, Beckmann 型光䉓比色計 $410 \mu \mathrm{m}$ て Optical Density (O.D.) を测定する。

9. 装準として Compound F $2 \%, 0.2 \mathrm{ml}$ エタノー

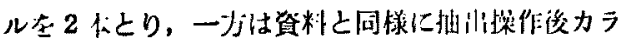

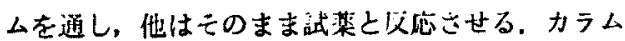
を通したすのはカラムStandard であり，直接試薬 と反応させたものより回収率を算定する.

10. 計算方法

$$
\begin{aligned}
& 2 \gamma \times \frac{\text { Sample のO. D. }}{\text { Standard O O. D. }} \div \text { Recovery } \mathscr{6} \times \\
& \frac{100}{\text { Plasma Vol }} \times 3 \\
& \text { Recovery } \mathscr{\sigma}=\frac{\{(\text { }}{\text { Stand } \text { のO. D. }- \text { Blank }} \\
& \frac{\text { Blank })\}}{\text { OO. D. }} \times 100
\end{aligned}
$$

使用した硫酸は三蕧化成工業株式会社の精密分析 用特級を，エタノール，メタノール，エチール醋酸、 クロロフオルムは和电純萬工業怢式公社の特級を精 製して使用した。

\section{実駼成 統}

\section{1) 刘照群}

対照佯の測定絬果は装 $1 ， 2 ， 3$ に示す迁りである。 男子においては総 17-OHCS 值は 14.0 41.87 g/dI で，汗均 $28.68 \pm 9.66 \mathrm{~g} / \mathrm{dl}$ を示し，そのうち遊離 型は $5.7 \sim 18.6 \gamma \mathrm{g} / \mathrm{dl}$, 平约 $10.37 \pm 4.28 \gamma_{\mathrm{g}} / \mathrm{dl}$ で, 結命型は 7.7 31.57 $/ \mathrm{dl}$ ご，平均すると $18.31 \pm$ $8.25 \gamma_{\mathrm{g}} / \mathrm{dl}$ となる. 結合型と遊離型の比をみた

\begin{tabular}{|c|c|c|c|c|c|c|}
\hline $\begin{array}{l}\text { 䆙列 } \\
\text { 番䲘 }\end{array}$ & 氏 名 & 年令 & Total & Free & Conj. & $\mathrm{C} / \mathrm{F}$ \\
\hline 1 & M. $\mathbf{K}$. & 47 & 22.0 & 9.8 & 12.2 & 1.24 \\
\hline 2 & H. T. & 30 & 14.0 & 6.3 & 7.7 & 1.22 \\
\hline 3 & J. K. & 31 & 15.5 & 7.5 & 8.0 & 1.07 \\
\hline 4 & N. M. & 26 & 41.8 & 14.3 & 27.5 & 1.92 \\
\hline 5 & M. H. & 26 & 31.9 & 13.7 & 18.2 & 1.33 \\
\hline 6 & M. Y. & 25 & 26.3 & 12.9 & 13.4 & 1.04 \\
\hline 7 & A. T. & 25 & 34.0 & 7.6 & 26.4 & 3.47 \\
\hline 8 & Y. F. & 25 & 25.4 & 7.3 & 18.1 & 2.46 \\
\hline 9 & M. s. & 25 & 37.2 & 5.7 & 31.5 & 5.52 \\
\hline 10 & Y. M. & 25 & 38.7 & 18.6 & 20.1 & 1.08 \\
\hline 平 & 均 & 値 & 28.68 & 10.37 & 18.31 & 2.03 \\
\hline 標 & 㴖 偏 & 差 & 9.66 & 4.28 & 8.25 & 1.45 \\
\hline 標 & 搳 & 琴 & 3.06 & 1.35 & 2.61 & 0.46 \\
\hline
\end{tabular}
$\mathrm{C} / \mathrm{F}$ 值は 1.04 5.52の筷围にあり，平枃すると $2.03 \pm 1.45$ となる。

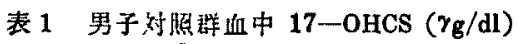

女子においては総 17-OHCS 值は 16.9 54.1 $\gamma_{\mathrm{g}}$ /dl の紽团にあり，平诗优は $32.85 \pm 13.53 \gamma_{\mathrm{g}} / \mathrm{dl}$

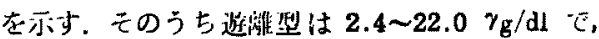
$10.35 \pm 5.38 \gamma_{\mathrm{g}} / \mathrm{dl}$ の平均值を示し，結合型は 11.7 $\sim 39.3 \mathrm{rg} / \mathrm{dl}$ て, 平均 $22.50 \pm 11.62 \mathrm{\gamma g} / \mathrm{dl}$ となる。 $\mathrm{C} / \mathrm{F}$ 值は 1.00 6.05 の範围にあつて平均する,

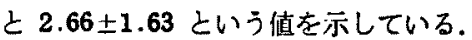

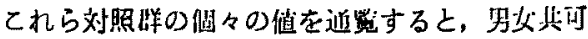
成り大きいバラッキがあり，又平均值よりす離れす ぎた值も $2 ， 3$ 見受けられる。総量においてす遊﨎型， 結合型も夫々可成りの扁差偡を示しているか， C/F 值については男女共すへて 1.0 以上の值を示してい る. 男女別の平均值を推娪学的に比校検討したが有 绑の差は誌められなかつた，従つて次の抑うつ状想 
表 2 女子対照群血中 17 -OHCS $\left(\boldsymbol{\gamma}_{\mathrm{g} / \mathrm{dl})}\right.$

\begin{tabular}{|c|c|c|c|c|c|c|}
\hline 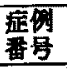 & 氏 名 & 年令 & Total & Free & Conj. & $\mathrm{C} / \mathrm{F}$ \\
\hline 1 & A. T. & 21 & 37.6 & 10.9 & 26.7 & 2.45 \\
\hline 2 & M. I . & 21 & 16.9 & 2.4 & 14.5 & 6.05 \\
\hline 3 & Y. T. & 21 & 53.6 & 17.9 & 35.7 & 1.99 \\
\hline 4 & S. K. & 18 & 26.6 & 11.4 & 15.2 & 1.33 \\
\hline 5 & S. S. & 18 & 25.5 & 11.3 & 14.2 & 1.26 \\
\hline 6 & K. M. & 18 & 42.2 & 8.4 & 33.8 & 4.04 \\
\hline 7 & $\mathbf{Y} . \mathbf{T}$. & 18 & 46.6 & 7.3 & 39.3 & 5.39 \\
\hline 8 & $\mathbf{Y} . \mathbf{M}$ & 18 & 28.8 & 6.7 & 22.1 & 3.29 \\
\hline 9 & S. Y. & 18 & 54.1 & 22.0 & 32.1 & 1.54 \\
\hline 10 & M. Y. & 18 & 18.2 & 6.5 & 11.7 & 1.80 \\
\hline 11 & Y. H. & 18 & 25.4 & 12.7 & 12.7 & 1.00 \\
\hline 12 & H. N. & 18 & 18.7 & 6.7 & 12.0 & 1.79 \\
\hline 平 & 均 & 倠 & 32.85 & 10.35 & 22.50 & 2.66 \\
\hline 標 & 偏 & 差 & 13.53 & 5.38 & 11.62 & 1.63 \\
\hline 標 & 蕉 愦 & 差 & 3.91 & 1.55 & 3.36 & 0.47 \\
\hline
\end{tabular}

群の検查結椙は一応状態像で䋁一し，性差を特别視 しなかつた。

2）抑うつ状態群

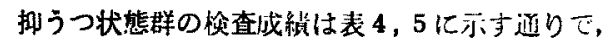
総量は 7.8 88.9 $\gamma_{\mathrm{g}} / \mathrm{dl}$ の範团にあつて, 平均値

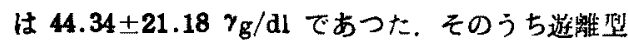
は $5.5 \sim 45.7 \gamma_{\mathrm{g}} / \mathrm{dl}$ の範囲で，平爫 $23.88 \pm 11.17$ $\gamma_{\mathrm{g}} / \mathrm{dl}$, 粘合型は $2.3 \sim 48.2 \gamma \mathrm{g} / \mathrm{dl}$, 平均 $20.93 \pm$ $11.43 \gamma_{\mathrm{g}} / \mathrm{dl}$ 示した。 $\mathrm{C} / \mathrm{F}$ 仵をみる上 $0.33 \sim 2.07$

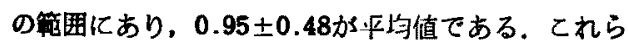
の値を対照群之比较すると，総量においては22例中 5 别か正常籍围化あつて，A例吕減少しており，13
例が増加した值を示し，平均値をみても明らかに堌 加の傾向加䇲われる，遊盛型においては 7例加正常 慨围内の值走し，減少したものは1例もみられず， 22例中の15例加增加し，平均値において 2 倍以上も 大きな値を示している. 又対招样で $10 \gamma_{\mathbf{g}} / \mathrm{d} !$ 以上 を示すものが22例中10例あるのに比して, 抑うつ状 態群では22例中18列が $10 \gamma \mathrm{g} / \mathrm{dl}$ 以上の値を示し, 中でも対照群ではみられない $25 \gamma_{\mathrm{g}} / \mathrm{dl}$ 以上の值を 示すむのが11例もみられる. 絬合型においては22例 中13例が正常筑囲内の值を示し，5例か减少し，4 例が增加している，対照群で $20 \gamma \mathrm{g} / \mathrm{dl}$ 以上を示す ものが 9 例あるのに此して，抑うつ状態群は12例で やや增加の傾向をみせ，平均値怙両群共大体近似し

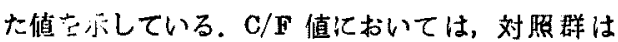
すへて 1.0 以上の俻を示すのに示すのに比して，抑 うつ状態群は借か 5 例か 1.0 以上を示し, 他はすへて 1.0以下の値であり，明らか維少の傾向を䜑めうる。

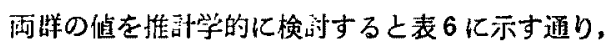

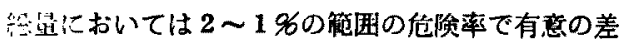
在認め，遊離型は0.196以下の伦険率で有意の差加 あり，絬合型では有意差なく， C/F 做においては $0.1 \%$ 以下の伦険率で有意の差を辣明しうる.

3）病型別にみた值について

てれら22例の排うつ状態の中には，男女共 2例ず つの反応性うつ病之，脳的㭛浭化症を伴う抑うつ状 熊 4 例があるが，抑うつ状䇛全体の血中 17-0HCS

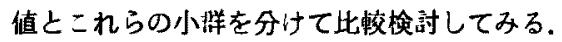

反応性うつ病群においては表 7亿示す通り，血中 17-OHCS 值は総量, 遊鉋型, 結合型, $\mathrm{C} / \mathrm{F}$ 值共

表 3 血中 17-OHCS 対照蛘一殞表

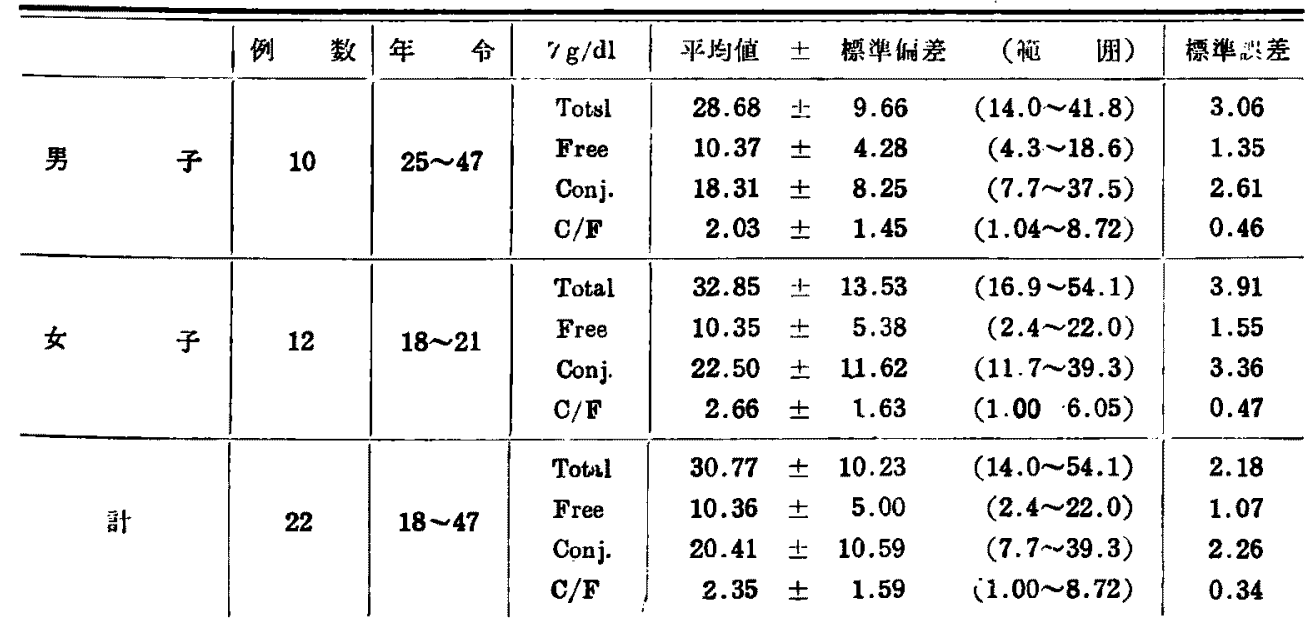


表 4 抑 5 状热群尿中-血中值

\begin{tabular}{|c|c|c|}
\hline & 氏名 & 症 \\
\hline 吸 & 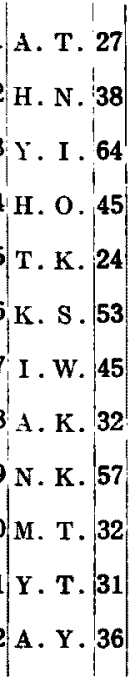 & 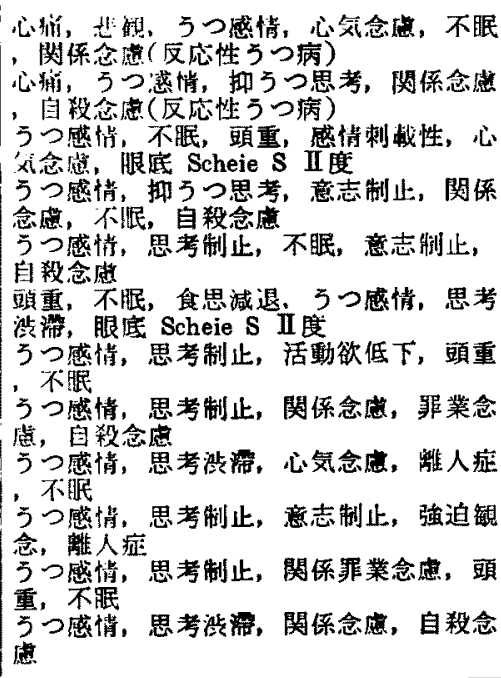 \\
\hline 女 & Y. T. 24 & 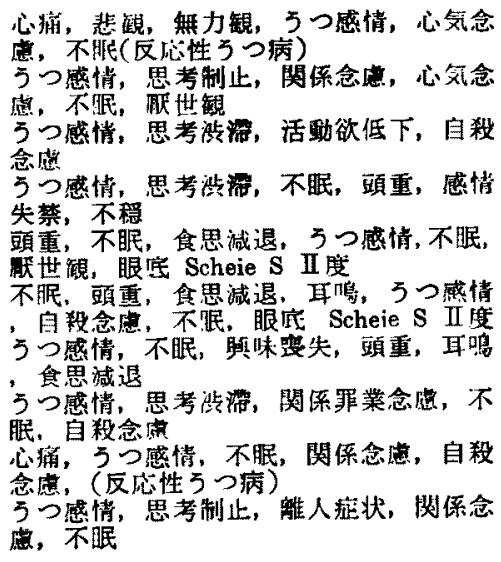 \\
\hline
\end{tabular}

表 5 血中 17-OHCS 㧕うつ状態群一紫表

\begin{tabular}{|c|c|c|c|}
\hline 例数年 令 & $\gamma_{\mathrm{g} / \mathrm{dl}}$ & 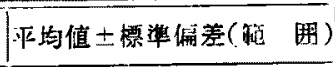 & 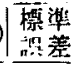 \\
\hline & Total & $44.34 \pm 21.18(7.8 \sim 88.9)$ & 4.5 \\
\hline & Free & $23.88 \pm 11.17(5.5 \sim 45.7)$ & 2.38 \\
\hline & $\begin{array}{l}\text { Conj. } \\
\text { C/F }\end{array}$ & $\begin{array}{c}20.93 \pm 11.43(2.3 \sim 48.2) \\
0.95 \pm 0.48(0.33 \sim 2.07)\end{array}$ & $\begin{array}{l}2.44 \\
0.10\end{array}$ \\
\hline
\end{tabular}

抑うつ状態全体の值と大差がない様である。

脳動脈硬化症を伴う抑うつ状態群においては表8

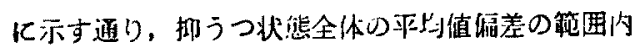
にあり，叙大差がない様であう。

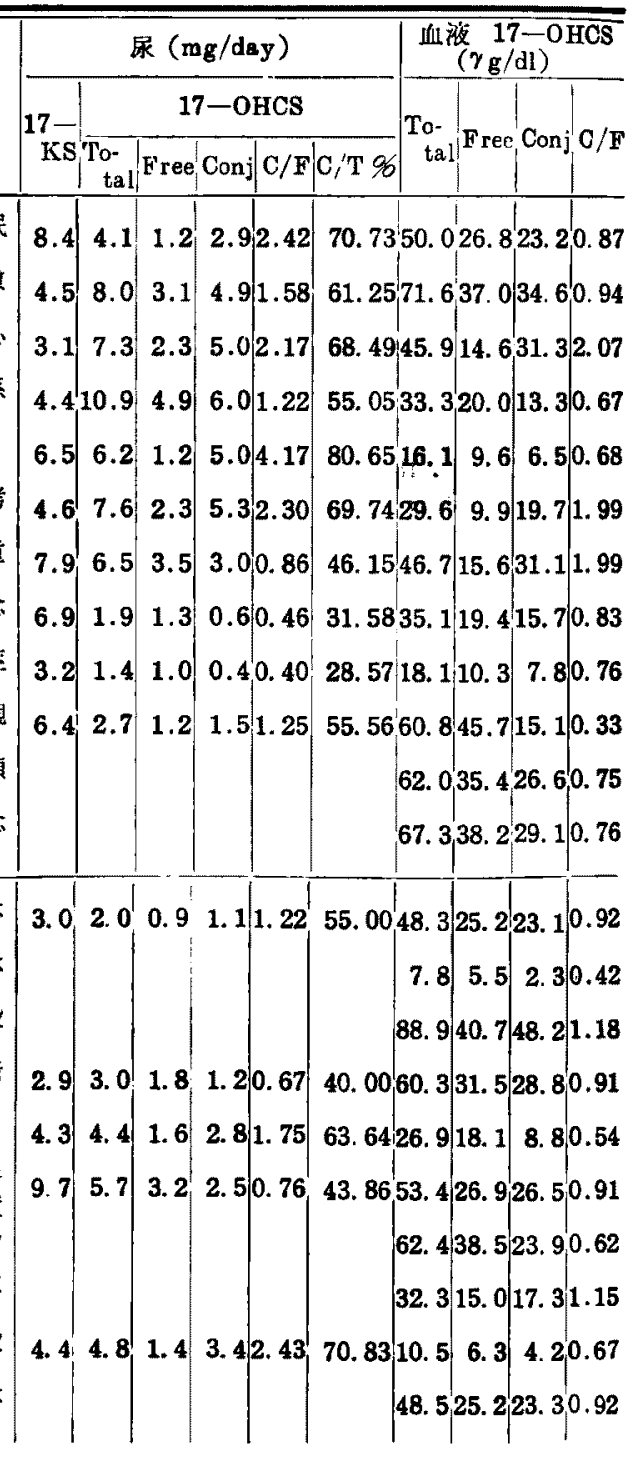

表 6 血中 17一OHCS 対照群と抑うつ状態群 との比較 $\left(\gamma_{\mathrm{g} / \mathrm{dl})}\right.$

\begin{tabular}{c|c|c|c|c}
\hline & Total & Free & Conj. & C/F \\
\hline 対 照 群 & 30.77 & 10.36 & 20.41 & 2.35 \\
抑うつ態群 & 44.35 & 23.88 & 20.93 & 0.95 \\
Student $\mathrm{T}$ & 2.642 & 5.220 & 0.156 & 3.888 \\
P \% & $2<1$ & 0.1 以下 & $90<80$ & 0.1 \%
\end{tabular}

4) 治療前後の值について

以上22例の抑うつ状態洋の犆は，前述した通りす ベて入院直後の未だ何ら治䝤を加えていない抑うつ 
状䈍時の血中 17-OHCS 值であるが，そのうち男子

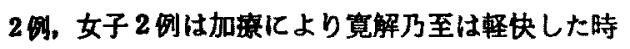
に再び血中 17-OHCS 值を剧定している，との4 例 について治痖前後の值を示すと因 1，表9の通りで

表 7 反応性了つ病群 $(\gamma \mathrm{g} / \mathrm{dl})$

\begin{tabular}{c|c|c|c|c|c}
\hline \hline & 虚烈 & Total & Free & Conj. & C/F \\
\hline 男 & 1 & 50.0 & 26.8 & 23.2 & 0.87 \\
子 & 2 & 71.6 & 37.0 & 34.6 & 0.94 \\
\hline 女 & 1 & 48.3 & 25.2 & 23.1 & 0.92 \\
子 & 9 & 10.5 & 6.3 & 4.2 & 0.67 \\
\hline 平均 值 & 45.10 & 23.82 & 21.28 & 0.85
\end{tabular}

ある，治潦前と比校して，治療後において17.0HCS 総量はすへて増加し，遊離型においては女子 Y.o. 例のみ增加して他は減少值を示し、結合型はすべて 增加している。 $\mathrm{C} / \mathrm{F}$ 值は治療前と比較してはるか

表 8 脳動脈硬化性亏つ状態群 ( $\left.\gamma_{\mathrm{g}} / \mathrm{dl}\right)$

\begin{tabular}{c|c|c|r|r|r}
\hline & 应例 & Total & Free & Conj. & C/F \\
\hline 男 & 3 & 45.9 & 14.6 & 31.3 & 2.07 \\
子 & 6 & 29.6 & 9.9 & 19.7 & 1.99 \\
\hline 女 & 5 & 26.9 & 18.1 & 8.8 & 0.54 \\
子 & 6 & 53.4 & 26.9 & 26.5 & 0.91 \\
\hline 平 均 & 值 & 38.95 & 17.38 & 21.58 & 1.34
\end{tabular}

因1治療前後の尿中血中17一OHCS 值

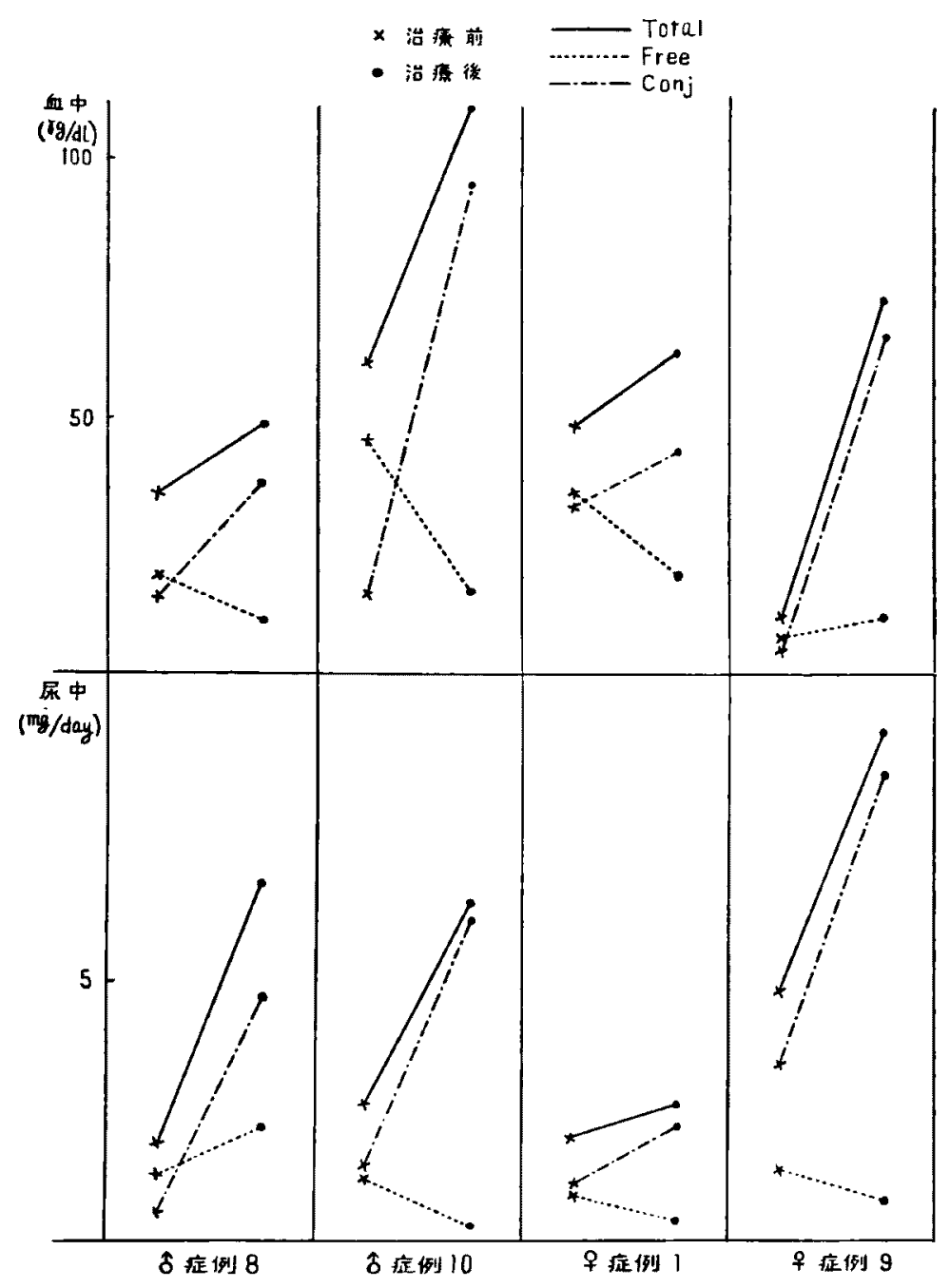


表 9 治癔前後の氺中・血中の值

\begin{tabular}{|c|c|c|c|c|c|c|c|c|c|c|c|c|c|}
\hline & \multirow{3}{*}{ 症例番号 } & \multirow{3}{*}{ 氏 名 } & & \multicolumn{6}{|c|}{ 尿（mg/day） } & \multicolumn{4}{|c|}{ 血液 $17-\mathrm{OHCS}\left(\gamma_{\mathrm{g}} / \mathrm{dl}\right)$} \\
\hline & & & & \multirow{2}{*}{ 17- } & \multicolumn{5}{|c|}{ 17-OHCS } & \multirow{2}{*}{ Total } & \multirow{2}{*}{ Free } & \multirow{2}{*}{ Conj } & \multirow{2}{*}{$\mathrm{C} / \mathrm{F}$} \\
\hline & & & & & Total & Free & Conj & $\mathbf{C} / \mathbf{F}$ & $\mathrm{C} / \mathrm{T} \%$ & & & & \\
\hline \multirow{2}{*}{ 男 } & \multirow{2}{*}{8} & \multirow{2}{*}{ A. $\mathrm{K}$. } & 治療前 & 6.9 & 1.9 & 1.3 & 0.6 & 0.46 & $\mid 31.58$ & \multirow{2}{*}{$\begin{array}{l}35.1 \\
48.2\end{array}$} & \multirow{2}{*}{$\begin{array}{l}19.4 \\
11.1\end{array}$} & \multirow{2}{*}{$\begin{array}{l}15.7 \\
37.1\end{array}$} & \multirow{2}{*}{$\begin{array}{l}0.83 \\
3.34\end{array}$} \\
\hline & & & 治療後 & 9.0 & 6.9 & 2.2 & 4.7 & 2.11 & 68.12 & & & & \\
\hline \multirow{2}{*}{ 子 } & \multirow{2}{*}{10} & \multirow{2}{*}{ M. T. } & 治療前 & 6.4 & 2.7 & 1.2 & 1.5 & 1.25 & $\mid 55.56$ & \multirow{2}{*}{$\begin{array}{r}60.8 \\
109.8\end{array}$} & 45.7 & \multirow{2}{*}{$\begin{array}{l}15.1 \\
94.5\end{array}$} & \multirow{2}{*}{$\begin{array}{l}0.33 \\
6.17\end{array}$} \\
\hline & & & 治療後 & 8.0 & 6.5 & 0.3 & 6.2 & 20.67 & 95.38 & & 15.3 & & \\
\hline \multirow{2}{*}{ 女 } & \multirow{2}{*}{1} & \multirow{2}{*}{ H. T. } & 治療前 & 3.0 & 2.0 & 0.9 & 1.1 & 1.22 & 55.00 & \multirow{2}{*}{$\begin{array}{l}48.3 \\
62.3\end{array}$} & 25.2 & \multirow{2}{*}{$\begin{array}{l}23.1 \\
43.4\end{array}$} & \multirow{2}{*}{$\begin{array}{l}0.92 \\
2.31\end{array}$} \\
\hline & & & 治憭 & 3.4 & 2.6 & 0.4 & 2.2 & 5.50 & $|84.62|$ & & 18.9 & & \\
\hline \multirow{2}{*}{ 子 } & \multirow{2}{*}{9} & \multirow{2}{*}{ Y. 0.} & 治癔前 & 4.4 & 4.8 & 1.4 & 3.4 & 2.43 & $\mid 70.83$ & 10.5 & 6.3 & 4.2 & 0.67 \\
\hline & & & 治療後 & 9.4 & 9.8 & 0.8 & 9.0 & 11.25 & \begin{tabular}{|l|}
91.84 \\
\end{tabular} & 76.8 & 10.1 & 66.7 & 6.60 \\
\hline
\end{tabular}

に上昇值を示し，すへて 2.0 以上の值を示してい る.

以上の様に抑うつ状態についていえることは，正 常対照群と比較して総量におりる軽度の増加，遊離 型の著明な増加による $\mathrm{C} / \mathrm{F}$ 值の明らかな縮少であ る. そして反応性うつ病, 脳動脈硬化症を伴う抑う つ状態時は，抑うつ状態全部加らみた時と大差なく， 治療前後に捄いて比較検討した場合，治療前の值は 治療により著しく改善され，正常值に近付くという 所見が明らかにされたわけである。

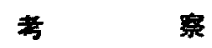

1）血中 17-OHCS 測定の意義と正常値

血中における 17-OHCS の動きは副筒皮質ホルモ ン全体を反映するもので, Nelson-Samuels1) の報告 以来, その化学的測定法は数々の変法が発表されて いる. 何れにしてあその根本となるるのは PorterSilber2) の呈色反応を応用したものである．その测 定法により，それらの正常值は必ずしも同一の值を 示してはいない，同時に副赑皮質ホルモンの日内変 動や，探血時におりる諸条件によつてあその值に偏 差加起る. 従つて探血時におりる条件を一定にし， 抽出・測定のための望差を最小にして比較検討しな ければならない，又女性においては，月経周期との 関係化伴う変動を考慮することは当然である。これ 迄の報告にみる諸家の值を表示すると表10の通りて ある.

Bliss ら3)は Nelson-Samuels の方法により血中 17-OHCS 遊離型を測定し，早朝が最高值を示し， 渐次低下して行き，夕方になるとやや増加する傾向
があるととを報告し，又 Reddy ら4）は6 人の成人 の総 17-OHCS 值を测定し, 午前 8 時30分探血時の あのは 28〜78 $\gamma_{\mathrm{g}} / \mathrm{dl}$ で, 平均 $46 \gamma_{\mathrm{g}} / \mathrm{dl}$ であつた の比して，午後 5 時採血時のあのは 15 197g/dl で，平均 $18 \gamma_{\mathrm{g}} / \mathrm{dl}$ であつたと報告している. 又 Doo

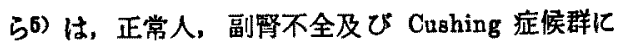
ついて各々の血中 17-OHCS 遊離型を测定し, 正常 人では夜更の21時から24時に最も低值で $1.9 \mathrm{\gamma g} / \mathrm{dl}$ であつたのに比して，6時から9時迄は最高值を示 し， $13.6 \gamma \mathrm{g} / \mathrm{dl}$ であつたと報告している.とれらの 報告例の共通点注早朝任血中 17-OHCS 值は最高で あるということである。著者の撰んだ早朝空腹時探 血比よる正常值は，遊雜型は外国の報告者の值より やや低く目の粎であるか，わが国の渡匀 ら6)，坂倉 ら7), 佐々木ら6) の值と大体一致している様である. これ迄の報告例は遊離型のみのあのが多く，同時侣 䊅合型を測定したものは少い様である.

Bongiovanni早(0) は牛肝加ら抽出した $\beta$-Glucuronjdase を使用して結合型を測定し，遊離型と結合 型はほぼ同じ漶度で存在していると報告し, 又 Weichselbaum (1) む $\beta$-Glucuronidase を用いて剆定 した結果，結合型は遊離型の約 $\mathbf{2}$ 倍近く存在すると 報告し，わが国では淁辺12が28例について遊離型と 結合型について測定しているか，その結果は表10に 示す通りである. 又勝又ら洨) す細菌性 $\beta$-Glucuronidase を用いて結合型を測定した結果，正常值は $10.4 \pm 4.7 \gamma_{\mathrm{g}} / \mathrm{dl}$ であり，同時に湘定した遊離型とは $1: 0.7$ 比を示したと報告している. 著者の測定し たとてろによれば遊離型は $10.36 \pm 5.00 \mathrm{\gamma} / \mathrm{dl}$, 結 合型は $20.41 \pm 10.59 \gamma_{\mathrm{g}} / \mathrm{dl}$ で, 結合型と遊離型の 
表 10 血中 $17-0 H C S$ 正常值 $\left(\gamma_{g} / \mathrm{dl}\right)$

\begin{tabular}{|c|c|c|c|c|c|c|c|}
\hline 告 & 测定法成用反店 & 例 & 数 & 遊 & 型 & 結 & 合 \\
\hline Nelson \& Samuels I) & P - S 反忍, N-S 法 & & 50 & & $(4 \sim 10)$ & & \\
\hline Silber \& Porter 2$)$ & S-P反心 & & 16 & $13.2 \pm 6.2$ & $(6 \sim 25)$ & & \\
\hline Bliss et al ${ }^{3)}$ & $\mathbf{N}-\mathrm{S}$ 法 & के & $\begin{array}{l}91 \\
21\end{array}$ & $\begin{array}{l}12 \\
15\end{array}$ & $\begin{array}{l}(2 \sim 34) \\
(2 \sim 31)\end{array}$ & & \\
\hline Bondy \& Altrock ${ }^{36)}$ & P - S 反心 & & 30 & $7.8 \pm 3.3$ & $(3 \sim 13.7)$ & & \\
\hline Doe et $\left.\mathbf{a} \mathbf{l}^{38}\right)$ & & & 13 & 12.7 & & & \\
\hline Sandberg et a $\mathbf{1}^{37}$ ) & P-S 反応 & & 84 & 13.0 & $(3 \sim 22)$ & & \\
\hline Eik-Nes 39$)$ & S-P 法変法 & & & & $(7 \sim 15)$ & & \\
\hline Peterson et al 40 ? & S - P 法変法 & & 50 & $1.5 \pm 4.5$ & $(6 \sim 25)$ & & \\
\hline 渡辺・熊谷6) & $S-P$ 法 & & 30 & $11.6 \pm 6.78$ & $(5 \sim 20)$ & & \\
\hline 井林41) & S, P 法 & & 12 & $13.5 \pm 9.95$ & $(3 \sim 36)$ & & \\
\hline 菊池(2) & $S-P$ 法 & & 24 & $12.0 \pm 5.15$ & $(0 \sim 26.2)$ & & \\
\hline 坂會・鉿末7) & $S \cdot P$-法変法 & ㅇ & 35 & $10.2 \pm 6.02$ & $(0 \sim 25.0)$ & & \\
\hline 佐ん木・勝又・草間8) & $\mathrm{S}-\mathrm{P}$ 法 & $\begin{array}{l}\hat{\delta} \\
\dot{+}\end{array}$ & $\begin{array}{l}50 \\
25 \\
25\end{array}$ & $\begin{array}{l}11.3 \pm 5.9 \\
11.6 \pm 6.2 \\
11.1 \pm 5.6\end{array}$ & $\begin{array}{l}(2 \sim 27) \\
(2 \sim 27) \\
(2 \sim 25)\end{array}$ & & \\
\hline Bongiovanni9)10) & $\begin{array}{l}\text { P.Glucuronidase } \\
\mathrm{N}-\mathrm{S} \text { 法 }\end{array}$ & & & $11.2 \pm 5.2$ & $.3 \sim 11.3)$ & $5.0 \pm 4.8$ & $(1.9 \sim 9.7)$ \\
\hline Weichselbaum et al 11) & $\begin{array}{l}\text { B-Glucuronidase } \\
N-S \text { 法 }\end{array}$ & & & $9.5 \pm 1.5$ & $(8.5 \sim 9.5)$ & ( & $(16.5 \sim 19.5)$ \\
\hline Brown et al ${ }^{43)}$ & & & & $12.5 \pm 0.5$ & & $10.4 \pm 0.6$ & \\
\hline Ceresa 44) & & & & $12.7 \pm 0.7$ & & $9.5 \pm 0.9$ & \\
\hline Kornel 45$)$ & & & & $13.4 \pm 2.8$ & & 14.3 & \\
\hline (Gore 48$)$ & & & & & $0.3 \sim 21.8)$ & & $(6.0 \sim 14.9)$ \\
\hline Steenburg 47$)$ & & & & $11.2 \pm 5.2$ & & $5.0 \pm 4.8$ & \\
\hline 渡辺12) & Butanol 抽出法 & & 58 & $14.4 \pm 11.0$ & & $43.1 \pm 22$. & \\
\hline 勝又・佐R木・草間(3) & $\beta$-Glucuronidase & & & $15.6 \pm 4.2$ & & $10.4 \pm 4.7$ & \\
\hline 著 者 & $\mid \begin{array}{l}\beta \text {-Glucurnidase } \\
\mathrm{N}-\mathrm{S} \text { 法 }\end{array}$ & $\begin{array}{l}\hat{\delta} \\
\stackrel{9}{q}\end{array}$ & $\begin{array}{l}10 \\
12\end{array}$ & $10.36 \pm 5.00(2$ & $.4 \sim 22.0)$ & $20.41 \pm 10.5$ & $59(7.7 \sim 39.0)$ \\
\hline
\end{tabular}

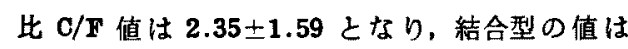
Bongiovanni の值よりも高值を示し，渡辺の值に大 体近似している様である。

次に性別，年令別については，Bliss ら3）が姓別 には特に大差なく，あつてあ僅かであり，問題とな らない之報告し，佐々木58）， Board ら4) 6同 様な意見で特に性差はない様てある。著者の值にお いてす特に性差はみられなかつた。年令的について Bliss ら3) は, 20〜45才の成人は2 34 $\mathrm{rg} / \mathrm{dl}$ の血 中 17-0HCS 遊㒕型值を示したが，64〜95才の老人 ては 3 24 $\gamma_{\mathrm{g} / \mathrm{dl}}$ で老人の方がやや低く目の様で あつて，平均値の上では大きな差はないが，範囲が 狭く，最高値加成人者と比較してはるかに低いとと を報告している，佐々木ら8)は10〜40才迄は大差 ないか，40才を越すと高値を示し，50才以上では明 ら加高値を示したと述へており，Bliss らの埌告
例とは異つた見解を表明している. Board ら14)に よると男女間は勿論，女子の閉経前後の間に特に 大差ないという. 以上の様に性差はないということ は諸家の一致した意見であるが，年令的新動につい ては諸説があり，尚統一された見解に至つていない． 湖してれらの報告による值がすへて遊離型のみの測 定によつており，結合型については精しい比较の值 がないた，その是非を諭じるととには問題があ る.

尚女子月経周期による血中 17-OHCS 值の変動に ついての報告は甚だ少いか， Pepper ら15)は12例の 月経周期について測定した結果，8例で排眆期前後 の48〜 72封間に最高值を示し，更に月経特にも高く， これらの時期には生体にストレス的团子が作用する ためであろうと述へている，著者はこの様な月释周 期上の関係を考慮して実験方法において述べた如く， 
月経第 1 日目より数えて第18乃至第23日目の間に採 血したもののみについて测定したわけであるが，著 者の用いた対照群女子は18 21才の思春期のもので あるため，Board らのいう閉経前後の值について精 しく触れることが出来ない，又，Bliss らや佐々木 らのいう成人と老人との血中 17.0HCS の值の差異 についても試料が成人層に限定されているため比較 に堪えない，乙の問題についても今後の研究に待つ 他はない。

2）血中ステロイドと所との関係

ステロイドホルモンの代謝に肝䠞，腎臓が重要な 役割を果し，甲状腺機能す関倸深いととはこれ迄の 多くの研究者によつて報告されている，Brownら16) は肝疾患患者飞 Cortisol, 或いは Cortisone 静 注すると，血中 17-OHCS 值の低下は正常の場合に

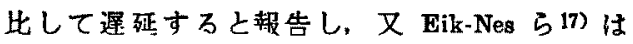
B.S.P. で闬機能を調べた結果と，Cortisol 或いは Cortisone 投与後の市中 17-oHCS 值低下の状態に 相関関係があることを浔めており， Englert ら18) 6 Cortisol 投与して血中 17-OHCS 遊離㤠の低 下する動きをみて，それは肝障害の強さに平衝して いると述べている。. Bongiovanni ら9) は肝硬変症患 者ではステロイドホルモン負荷後は血中結合型 17OHCS 值方著明儿隇少することを述へ，その他渡

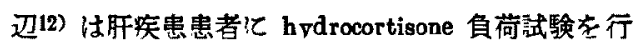
い血中 17-OHCS 矵定して, 肝障害特には負荷 hydrocortisone の血中よりの消失速度が荤延すると とを認め，肝障害とコルチコイド代懒との関係につ いて報告をしている。

著者はこの様な訮脿とステロイドホルモンとの関 係を考慮にいれて，一般肝㙨能検査を行い，異常の なかつた抑うつ状態群について測定した。

高血圧症之血中 17.0HCS 值との関係とついては, 西川ら19）によると高血圧症患者は血中 17-OHCS 遊離型が一般㣂高值をるるのが多く，時々 30〜 $40 \mathrm{rg} / \mathrm{dl}$ の暴常高檤を示し, その変動の巾も大き く，而も比较的若年の高血圧症者にこの傾向が著し いと述へているか，高血圧症との関係は遊離型のみ ではその本態解明は難しい。

3）精神疾患時の血中 17-0HCS 飞ついて

中枢神経系，特に視床下部加 ACTH 分泌調節に 関与しているととは広く認められているか220)，特殊 な情緒反沁之 ACTH 分泌間の関係については今日 尚殆んど知られていない，Selye21)によると苦缩な 体験はストレッサーであり，それによつて誘発され
た精神身体面の防衛活動は適応症候群の姿をとるわ けであり，心身面の随伴現象はいわゆる適応性変化 とみなされ，脳下垂体及び副等皮質の不適切なホル モン分泌借くあのといっている，下垂体副特皮犋 系のストレス下の変化について, Sayers22) 仙副驽 皮質抽出物を投与すると ACTH の分泌诚少，副留 萎縮を起し，一方副督皮質抽出物注射後の動物沉，軽 度或いは中等度のストレスを与えても ACTH の分 淡を起さないととから，ACTH 分泌は副督皮質木 ルモンの血中濃度により調節されているという説を 支持している.すなわちストレスが加わると末梢組 織は副腎皮質ホルモンを比較的急速汇消費するため， ホルモンの血中濃度は低下し，乙れか直接に，或い は又視床下部を経て下垂体前葉を刺戟して ACTH 分泌量加增加し，副腎皮質ホルモンの增加を来たす というととになる。

精神的緊張がストレスとして㗢き，生体の防覙反 応を刺戟するととは多くの研究報告がなされており， 中でも Persky ら23224) は軽い神経症で入院中の21 名の患者汇精神的不安を惹起させる椂な問題を与え てから, 血中 17-0HCS 遊離型在測定した結果, 対 值群化比して60\%の高值を示したと述へ，又正常人 に対して stressful interview を行い，その反応と 血中 17-OHCS 值の変化を調べた結果, 苦しみとか, 怒りとか，歪うつなどの感情が深まるにつれて，血 中 17.0HCS 值も上昇したが, 特に 17-OHCS 值存 上昇させる様な特種な情緒反応はなかつたと報告し ている.

Board 525) は精神的ストレスと内分泌機能の相 関を血中 17-0HCS と甲状腺ホルモンを指慓として 研究した結果, 新しい精神病入院患者 30 名の早朝空 腹時の血中遊離型 17-OHCS 值加 $19.8 \pm 7.3 \gamma_{\mathrm{g}} / \mathrm{dl}$ であるのに比して，対照群では $12.3 \pm 6.1 \gamma \mathrm{g} / \mathrm{dl}$ という值を示した．又精神病者の方は60\%す值が高 く，日内変動による低下が少かつた，又そのうち11 名の神経症性うつ状態の患者は $16.4 \pm 5.2 \gamma \mathrm{g} / \mathrm{dl}$ で， 対照群と比較して有意の差を認め，10名の内因性う つ病者では $22.2 \pm 6.3 \gamma \mathrm{g} / \mathrm{dl}$ でやはり有意の差加 あつたが， 5 名の分裂病者は $18.1 \mathrm{~g} / \mathrm{d} 1$ で有意の 差を認めえなかつたと報告している．Board ら14) は又，33名のうつ状態患者の血中遊離型 17-OHCS 值を測定した所，平均 $19.5 \% \mathrm{~g} / \mathrm{d} 1$ で，対照群より 5996高値を示し，最も抑うつ状態のひどい9名は $23.7 \gamma_{\mathrm{g}} / \mathrm{d} 1$ で，対炤群より92\%高值を示した之報告 している，著者の抑うつ状態における血中 17-OHCS 
值は Board らの值之同様に遊﨎型は明らかに增加 しており, 対照群が $10.36 \pm 5.00 \mathrm{rg} / \mathrm{dl} に$ 対し, 抑うつ状態群では $23.88 \pm 11.17 \gamma_{g} / \mathrm{dl} て ゙$, 対照群 の 2 倍以上に相当する值を示したととは Board ら の值と全く近似している．抑うつ状態において結合 型を刷定した文轴は見当らない様であるが，著者の 場合は血中稳 17-OHCS の面において22例中 5 例が 正常䉇围仁あり，4例が減少し，13例加增加し，全 体的にみると抑うつ状態において多少の増加の傾向 を睍いうるが，平均値をみると大差ない様である。 遊離型之結合型の比 $\mathrm{C} / \mathrm{F}$ 值では，対照群之比较し て明らかに娍少しており，0.196以下の危険率で有 意差を認めうる. これは従来の報告にはみられない 所である.

Blise ら 26)27) は主として分裂病についい研究し， 20 45才の正常群では早朝空腹時の血中遊離型 17OHCS 值が平均 $13 \pm 6 \gamma_{\mathrm{g}} / \mathrm{dl}$ であつたのに対して, 20 40才の慢性分裂病者では $14 \pm 6 \gamma \mathrm{g} / \mathrm{dl}$ という 值を示して有意の差を認めえなかつたが，興丵の激 しい分裂病では $22 \pm 8 \mathrm{rg} / \mathrm{dl}$ で196以の危険率 で有意の差を認めたと報告している. Persky ら28) は入院して 5 年以上経過した慢性分裂病者の血中 17-OHCS 值は正常であつたと報告し, 教室の高坂 万29)は血中 17-OHCS 值は，分裂病者加対照群に 比して遊離型は大で，結合型が少く， $\mathbf{O} / \mathbf{F}$ 值をみ ると対照群が0.8以上であるのに対して, 分裂病群 は0.8 以下のあのが多いと報告している. その後症 例を追加検討してまとめた分裂病群の平均值を示す と表11の通りである49).これを著者の抑うつ状態群 と比較すると, 総量において抑うつ状態群は分裂病 群の約 2 倍を示し，遊離型においても同じく㧕うつ 状態群は分裂病群の約 2 倍值, 結合型も同様汇 2 倍 以上の高値を示している． C/F 值机いては分裂病 群がやや低く目の様であるが偏差の巾が大きいため, 抑うつ状態群と余り大差ない様でるる。てれらの分 裂病群と抑うつ状態群を推計学的に検討すると表 12 に示す様に総量，遊離型，結合型共に0.196下の 危険率で有意の差が証明れる， C/F 值のみは有意差 がない. 又教室の高坂 ら30)は女子陳旧性分裂病患 者に Cortisol Infusion Test を行い, 血中 17-OHCS の結合型，遊離型の排泄曲線は丁度肝障害者や高令 者にみられる様な曲線に近似しており，体内におす るCortisol 結合能の低下を示すと報告している.

うつ病乃至は抑うつ状態の生化学的研究について 振り返つてみると,Georgi ${ }^{311}$ が抑うつ状癿では空腹
表11 分裂病血中 17-OHCS ( $\left.\gamma_{g} / \mathrm{dl}\right)$

\begin{tabular}{|c|c|c|c|c|}
\hline 例数 & 年令 & $\gamma_{g} / d l$ & 平均値士標偏差(範 囲) & 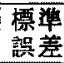 \\
\hline & & Total & $23.51 \pm 12.55(2.3 \sim 50.8)$ & 3.14 \\
\hline & & Free & $13.91 \pm 8.08 \quad(1.0 \sim 25.7)$ & 2.02 \\
\hline & $18 \sim 30$ & Conj & $9.72 \pm 7.17 \quad(1.3 \sim 1.60)$ & 1.79 \\
\hline 計16 & & $\mathrm{C} / \mathrm{F}$ & $0.83 \pm 0.84(0.30 \sim 3.40)$ & 0.21 \\
\hline
\end{tabular}

表12 血中 17-OHCS 抑うつ状热群と分裂 病群との比较 $(\gamma \mathrm{g} / \mathrm{dl})$

\begin{tabular}{c|c|c|c|c}
\hline \hline & Total & Free & Conj. & C/F \\
\hline 抑 万つ状態群 & 44.35 & 23.88 & 20.93 & 0.95 \\
裂 病 群 & 23.51 & 13.91 & 9.72 & 0.83 \\
Student T. & 10.742 & 9.403 & 12.595 & 1.739 \\
P 96 & 0.1 以 & 0.1 以下 & 0.1 以下 & $10<5$
\end{tabular}

時コレステロール値が上昇する場合が多く，正常人 では朝食前にコレステロール值が低下する傾向を示 すのと対照的であると述へている，Muller ${ }^{32)}$ はう つ病患者の睌眼之覚醒, 疲労と回復の交代に伴つて 血中イオンの移動䚮あるといい，Staub33) は60人の 抑うつ状態患者について血糖二重負荷試験を行い， 血糖の上昇を認めたが，そのうち12名の心因性抑う つ状態を示す患者では血糖值の上昇は認められず， 不安焦燥感の強いうつ病の14例では空腹時血糖值は 正常より高く， 2 回目のブドウ糖投与後の血糖値の 恢復曲線は正常上りあ達延することが認められ，長 時間観察の結果, 血糖目荷試験曲線と血中コレステ ロール変動曲線には異常があり，それが抑うつ状態 の軽块之はほ平行して正常に復するととが分り，抑 うつ状態の程度と糖代謝能力の低下, コレステロー ル代謝障害の 3 者の間任相関関係があり, 診断上の 助けになると述へている，血中コルチコイドと血糖 值の增減については直接的技実証に乏しい，併し臨 床治療の目的で合成 17-OHCSを投与するとしばし ば血糖值の上昇を薏起する，それが末梢におけるイ ンシュリンの作用を浉制するためであるのか，或い は又 Glucagon の傎きを促進せしめるか現在不明で ある. 併し著者の測定した血中遊離型 17-OHCS 值 の増加という成績は Staub の血糖上舁を説明する 側に立ち，且つ血中コレステロール増加を来すとい う Georgi の見解とも矛盾しない。

抑うつ状態における血中 17-0HCS 像は，総量に おいて明らかな增加を示し, 遊離型においては対炤 群に比して 2 倍以上の上昇值を示した成嚗は Board 
らの結果と大体一政している．結合型を抑うつ状热 において検査したのは著者が始めてであるため他と 比較検討することは出来ないか，結合型と遊離型の 比 $\mathbf{C} / \mathbf{F}$ 值においては対照群とかり䧼れた縮少を示 すととが明らかであり，とのととは未知の所㖏蹇を 含めたコルチコイド代謝障害と，情緒の変化任対す ろ視床下部の役割及びそてにあると考えられている Corticotrophin Releasing Factor の䟼活加共に関係 するあのであり，抑うつ感情に導く代謝障害の有無 について考えなくてはなるまい。

4）血中、尿中コルチコイド値変動の相関 血中值と尿中値の相関関係儿ついては，今迄の報 告例にみる通り，しばしば解離するあので，実際に はどちらが優先して副堅皮質機能を示すか解积に苦 しむ場合が多い，乙の機序汇関しては服，甲状腺， 性腺などの関与するととが明らかであり，その間の 相関関係が渐次分りつつある. 併し复雜な生体反応 の経過の途中において内分泌機能のみが画一的な画 像を呈することはありえず，先行した変化に次ぐ第 二次の変化が起り，それが又近路をして先行するも のに影䇾を与えるという様なととは生化学的な反応 過程には常に存在するととである.

西川ら34)は臨休的に明らかな Cushing 症候群で ありながら，頻回に測定した尿中 17-OHCS 值は正 常範囲にあり, 血中遊離型 17-0HCS 值は 23〜31 $\gamma_{\mathrm{g}} / \mathrm{dl}, 51.8 \gamma_{\mathrm{g}} / \mathrm{dl}$ などの高值を示した 2 例を経験 し, 逆に又 Addison 病で血中遊離型 17-OHCS 值 は正常値を示すが尿中值 0 という症例 経験し， Anorexia nervosa では尿中值は著しく低下するが， 血中值は略々正常であつた症例も報告している. Brown 535) は甲状腺機能穴進症では逆傜中值に 比して尿中値が高い値を示すととを報告し，高血圧 者では血中値が高値を示すのに比して，尿中值がそ れ相応しない場合あある19)。勿論血中值はそれら の状態の程過中のある限られた時間における值であ り，腎クリアランス関門を経過した後の尿中值との 解離住理解しうる所である。

著者の測定した22例の抑うつ状態時における血中 17-OHCS 值の特徽は, 㥹量において22例中 13 例か 堌加し, 平均值の推計学的検討でも $2 \sim 1 \%$ の危険 率で有意差があり, 又遊離型は22例中15例加増加し て, 平均值において対照群の 2 倍以上の上昇值を示 し, 結合型は対照群と大差ないが， C/F 值の縮少は $0.1 \%$ 以下の危険率で有意差加認められるととであ つた，乙れら22例中同時に尿中 17-KS，17-OHCS

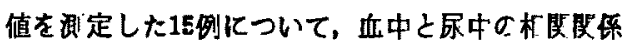
を比校检討してみることにする.（表 4参照）

尿中 17-KS は抑うつ状態において減少值を示し， 17-OHCS 総量も低下の㑯向を示している. 遊離型 では尿中值は男女共正常対照值の 2 倍以上の増加を 示し，結合型は男女共減少し， C/F 值は著明な減少 を示している. 血中 17-OHCS 值が括離型正常值の 2 倍以上の增加を示すととと、 C/F 值加著昵に減 少する点は尿中, 血中共に相通じる所見であるか， 血中 17-OHCS 総量の上昇は必ずしも尿中の 17OHCS 総量の増加を意味しない，又尿中 17-OHCS 結合型が低下しているのに対して血中值は対炤群と 大差がないととは血中コルチコイトと尿中コルチコ イドの意味の相異を示哓し，その相巽を疾患或いは 状態像との関連と結びつけられるか否かが今後の問 題であろう.

分裂病における尿中，血中の 17-OHCS 像の関係 について小林48）の尿中值と比較して考察する. 小 林によると，尿中分裂病新鮮群 17-OHCS 総量は対 照群に比して増加しており，遊離型は 2 倍以上の上 昇值を示し，結合型がやや上昇し，その結果 $\mathbf{C} / \mathbf{F}$ 值は著明に減少するが, 慢性群 17-OHCS 総量は対 照群と大差なく，遊離型は 2 倍以上上昇し，結合型 が低下して，その結果 $\mathrm{C} / \mathrm{F}$ 值は著明に隇少すると 述へ，新鮮群，慢性群共に遊離型の 2 倍以上の上㫒 之， C/F 值の低下が共通する所見の様である. 高 坂ら49)の報告した分裂病16例では，血中 17-OHCS 総量は対照群に比して著明に減少し，尿中值之全く 異つた所見を示す。遊離型は対照群と大差なく，尿 中値とは全く異つている. 結合型は対照群の $1 / 2$ 以 下に減少していて，尿中值とは異つた所見を示して いる. C/F 值の著明な縮少は㽷中, 血中共に共通 する所見でる．乙の样に尿中, 血中共に $\mathrm{C} / \mathrm{F}$ 值 が対展群と比較して著明に低下しているととは，抑 うつ状驡群の尿中, 血中の $\mathrm{C} / \mathrm{F}$ 值の低下をむたら す機序とは大いに異るところである。

次に表 9 亿示す様に，4例の治療前後の尿中，血中 17-OHCS 值をみるに，萎縮した治療前の尿中総 17OHCSの值汃治療後においては総体的に増加し, 反対 に遊離型は男子A. K. 例を除いては減少して, 結合型 はすへてて増加し， C/F 值の著明な上昇を示している. 血中において遊離型の減少，結合型の増加， $\mathbf{C} / \mathbf{E}$ 值の 上昇は尿中コルチコイド像の改善と同じ傾向である か，総 17-OHCS は正常値より高いとてろから更に 高く飛躍している，併しての高腾は症状の改善後克 
分な日時をおいて测定すれば，おそらく治療前の値 より低下して正常值佰近い値を示しているであろう. 㱏状改善のために血中 17-0HCS の総量が一旦增加 する所見は極めて興味ある事実といわなければなら ない.

以上のとと加ら抑うつ状態においては，血中 17OHCS 值は対照群と比校した場合, 総量の増加と, 結合型は大差ないが遊離型の著明な堌加に伴い $\mathrm{C} / \mathrm{F}$ 值が通かに減少することが明らかになつた，又分裂 病群においては䋓量加対照群上りも低值を示すにも 拘わらず，遊離型は対炤群と大差なく，逆侸合型 が対照群の半分以下の低值を示すととによつて C/F 值が減少している，抑うつ状態における $\mathrm{C} / \mathrm{F}$ 俻縮 少の主因は結合型の縮少ではなくて，遊離型の增大 であり，その点分裂病とその赴を異にしているわけ である.

血中 17-OHCS の遊離型と結合型のすつ意味には 夫々異つたものがあると考えるのが普通であろう. 即与遊離型の増減は直接間脳一下垂体一副腎皮質系 機能の緊張度を反胦し，結合型の增減は肝機能を含 めた全身代謝に多くの比重をるたせるものではなか ろうか. これ迄の测定結果が教えてくれるあのは分 裂病と抑うつ状隼の Corticoid pattern 加ら推量さ れる両疾患の相異が前者では主に Diencephalonを 中心とした中枢性のものであり，後者では中枢と末 梢を含めたより全身性のものと考えるべきではなか ろうか. てれらの解明は今後の綜合的な研究の結果 をまつ他はないか，等しく内因性精神病と呼ばれて いるとの両疾患の相異について一つの重要な判定資 料を提供するものと考えたい。

\section{結語}

1）健康な男子10名と女子12名を対照群として。 反応性うつ病 4 例，脳動脈硬化を伴う抑うつ状態の 患者 4 例を含む計22名のうつ病乃は至抑うつ状態者 の血中 17-OHCS 総量, 遊踓型, 結合型を測定した。 刷定方法は Nelson-Samuels 及び Bongiovanni の方 法であり，結合型の水解飞は牛肝 $\beta$-Glucuronidase を使用した。
2）その結果, 総量においては22例中13例が増加, 遊離型では22例中15例が堌加しており，結合型は男 女共対照群と大差ないか， C/F 值において著明な 縮少を示した。総量, 遊離型， $\mathrm{C} / \mathrm{F}$ 值は夫々推計学 的にも対照群と比較して有意差を証明した。

3）反忘性うつ病，脳動脈硬化を伴う抑うつ状態 等を夫々小群に分けて比較したが，全抑うつ状態群 と大差なかつた。

4）治療前と治療により軽快，又は寛解したもの 4 例について血中 17-0HCS を測定し, 病状の改善 に伴つて対炤群の值に近付き，減少した $\mathrm{C} / \mathrm{F}$ 值が 著しく增加するととを認めた。

5）分裂病と比較し， C/F 値が低下することは抑 うつ状態時と共通する所であるか，分裂病者は結合 型が隇少して C/F 值が低下し, 抑うつ状態では遊 離型が著明に増加するために $\mathrm{C} / \mathrm{F}$ 值が減少する点 が相異点であるととを知り, それの持つ意味につい て考察した。

6）15例の血中，尿中 17-OHCS 值を同時飞測定 したものについて比较した所, 血中遊離型の增加は 尿中遊離型の堌加を招き， $\mathrm{C} / \mathrm{F}$ 值の低下の直接原 因となる. 又血中総量の増加は必ずしる尿中総量の 増加を意味せず，更に血中結合型と尿中結合型値の 増減か平行しない等を知り，その意味について間脑 一下垂体及び肝機能の受け持つ役割りと病因につい て考察した。

（本論文の要旨は第16回中国四国精神神経学会K末 いて発表した. )

稿を䅂ると臨み，御校閲を睗わりました奥村二吉 教授に，又実駼の総てについて直接御指導下さいま した高圾睦年助教授に深謝致します。

尚実験御協力下さいました県立岡山病院精神科 並びそ当精神科医局の諸先生及び実験助手を勤めて 下さつた中山筧子，金沢千嘉子の御両名飞厚く感謝 政します。 
1) Nelson, D. H. \& Samuels, L. T.: J. Clin. Endocrinol. \& Metab.; 12, 579, 1952.

2) Silber, R. H. \& Porter, C. C.: J. B.C.; 185 , 201, 1950.

3) Bliss, E. L. et al.: J. Clin Invest.; 32, 818, 1953.

4) Reddy, W. J. et al.: J. Clin. Endocrinol. \& Metab.; 16, 380, 1956.

5) Doe, R. P. et al.; ibid.; 20, 252, 1960.

6）渡辺富久子他：日内分必誌； 32,127 , 昭30.

7）坂会哲夫他：ホルモンと臨床；9，182，昭36。

8）佐々木英夫他：ibid；9，845，昭36.

9) Bongiovanni A.M. et al.: Proc. Soc. Exp. Biol. \& Med.; 87, 283, 1954.

10) Bongiovanni, A. M. \& Eberlein, W.R.: ibid; 89, 281, 1955.

11) Weichselbaum, T. E. \& Margraf, H. W.: J. Clin. Endocrinol. \& Metab.; 15, 970, 1955.

12）渡辺富久子：奈良医誌；11，911, 昭35.

13）勝又愁子他：ホルモンと臨床；10，419, 昭37.

14) Board, F. et al.: AMA Arch. of Neurol. \& Psychiat.; 78, 612, 1957.

15) Pepper, H. \& Lingdasy, S.: Proc. Soc. Exp. Biol. \& Med.; 104, 145, 1960.

16) Brown, H. et al.: J. Clin. Invest.; 33, 1524, 1953.

17) Eik-Nes, K. et al.: Acta endocrinol.; 18, 244, 1955.

18) Englert, E. \& Brown, H.: J. Clin. Endocrinol. \& Metab.; 17, 1395, 1957.

19）西川光夫他：内科；8，251, 昭35.

20) Harris G. H.: 脳下垂体の神経調節；医菌薬出 版, 東京, 昭33.

21) Selye, H.: J. Clin. Endocrinol.; 6, 117, 1946.

22) Sayers, G.: Physiol. Rev.; 30, 241, 1650.

23) Persky, H. et al.: AMA Arch. Neurol. \& Psychiat.; 76, 549, 1956.

24) Persky, H. et al.: ibid.; 76, 434, 1958.

25) Board, F. et al.: Paychosom. Med.; 18, 324,
1956.

26) Bliss, E. L. et al.: The Am. J. of Psychiat.; 112, 358, 1955.

27) Bliss. E. L. et al.: Psychosom. Med.; 18, 56, 1956.

28) Persky, H. \& Sabshin, M.: ibid; そ2, 218, 1960. より引用

29）高坂睦年他：精神経誌；62，727，昭35.

30）高坂㓐年：最新医学；14，8，昭34.

31) Georgi, F.: Schweiz, Med. Wach.; 74, 539, 1944.

32) Müller, L. R.: Ửber den Schlaf ; 2 Aufl, Urban, 1948.

33) Staub, H.: Helv. Med. Acta.; 14, 615, 1947.

34) 西川光夫他：内科；6，167，昭34.

35) Brown, H. et al.: J. Clin. Endocrinol. \& Metab.; 18, 167, 1958.

36) Bondy, P. K. \& Altrock, J. R.: J. Clin. Invest.; 32, 703, 1953.

37) Standberg, A. A. et al.: ibid.; 33, 127, 1954.

38) Doe, R. P. et al.: J. Clin. Endocrinol. \& Metab.; 15, 943, 1955.

39) Eik-Nes, K.: ibid; 17, 502, 1957

40) Peterson, R. E. et al.: Anal. Chem.; 29, 144, 1957.

41）并林 博：木ルモンと踟床：5，1161，昭32。

42）釉地顺一郎他：日内分泌誌；33，448, 昭31.

43) Brown, H. et al.: J. Clin. Endocrinol.; 17, 1191, 1957.

44) Ceresa, F. \& Cravetto, C. A.: Acta endocrinol.; 29, 321, 1958.

45) Kornel, L.: J. Laborat. Clin. Med.; 54, 659, 1959.

46) Gore, M. B. R. \& Baron, D. H.: J. endocrinol.; 21, 303, 1960.

47) Steenburg, R. W. et al J. Clin. Endocrinol.; 21, 39, 1961.

48）小林潤三：岡山医誌；74，659，昭37。

49）高坂睦年他：策 16 回中国四国精神神経学会口 演；昭37. 


\title{
Studies on Diencephalo-Pituitary-Adrenocortical Function in Depressive Psychosis
}

\author{
II. On Blood Corticoid Patterns
}

\author{
By \\ Harunori Tsuji \\ Department of Neuro-Psychiatry, Okyama University Medical School \\ (Chicf : Prof. Nikichi Okumura, M. D.) \\ (Directed by Dr. Mutsutoshi Kohsaka, M. D., Associate Professor)
}

\begin{abstract}
Author's Abstract
As the result of investigation of the urinary steroid patterns in depressive psychosis in previous communication, the author has been able to demonstrate the decreased excretion of total 17-ketosteroid (17. KS) and total 17-hydroxycorticoid (17.0HCS), increased excretion of free 17.0HCS and decreased excretion of conjugated 17-OHCS. Following these results, the ratio of conjugated form/ free form (C/F) and the percentage of conjugated form/total 17$\mathrm{OHCS}(\mathrm{C} / \mathrm{T} \%)$ seem to have very significant changes in comparison with those in the control. In the present study the author investigated 17-OHCS in plasma of depressive psychosis.

The plasma specimens were secured from 10 males and 12 females, all healthy persons (in the age range of 18-47 years old and 23 years in average) for controls, and 12 male and 10 female depressives (ranging 22-64 years in age, the average being 41 years). Measurements were taken on total, free and conjugated forms of 17-OHCS by Nelson-Samuel's and Bongiovanni's methods and for the hydrolysis of conjugated form beef-liver $\beta$-glucuronidase was employed.

The results are as follows: (Every value shows mean and standard deviation.)

1. Total 17.0HCS values were $30.77 \pm 10.23 \mathrm{rg} / \mathrm{dl}$ for controls and $44.34 \pm 21.18 \mathrm{rg} / \mathrm{dl}$ for depressives, and those of free form were $10.36 \pm 5.00 \mathrm{rg} / \mathrm{dl}$ in controls and 23.88 \pm 11.17 $r_{\mathrm{g}} / \mathrm{dl}$ in depressives, those of conjugated form were $20.41 \pm 10.59 \mathrm{rg} / \mathrm{dl}$ in controls and 20.93 $\pm 11.43 \gamma_{\mathrm{g}} / \mathrm{dl}$ for depressives and $\mathrm{C} / \mathrm{F}$ ratio was $2.35 \pm 1.59$ in controls and $0.95 \pm 0.48$ in depressives.

2. In comparison with depressives and controls, the total 17-OHCS was higher than normal value, being significant from the statistical standpoint. The value of free form was about 2 times higher than the normal, showing significant difference between the two. The C/F ratio in depressives, however, was about half of the normal value.

3. In comparing all the depressives with the small groups of 4 reactive and 4 cerebral arteriosclerotic depressives, there could be found not any specific differences among them.

4. In the four cases with improvement after treatment it was found that total 17-OHCS was increased, free form decreased and conjugated form increased. As the result of these changes, $\mathrm{C} / \mathrm{F}$ ratio was also increased and the corticoid pattern approached the normal value.

5. The decrease in $\mathrm{C} / \mathrm{F}$ values was characteristic common both to schizophrenia and depressive, but a difference between the two was found in the fact that, whereas the $\mathrm{C} / \mathrm{F}$ value was decreased due to a clecrease in conjugated form in schizophrenia, it was diminished as the result of a marked increase in free form in the depressive. A discussion was made on the meaning of these findings.
\end{abstract}


6. In the comparative values of $17.0 \mathrm{HCS}$ in the blood and urine of 15 cases, measured simultaneously, it was found that the increase of free 1.7-OHCS in the blood induced an increase of the free 17-OHCS in the urine, thus directly causing the diminution of $\mathrm{C} / \mathrm{F}$ value. In addition, it was clarified that an increase of total blood 17-OHCS did not necessarily mean its increase in the total urinary content, and also there was no parallel increase in its values of conjugated form in blood and in urine. In order to explain this point, a discussion was made on the role played by the diencephalon, hyophysis and liver function as well as on the pathological factors. 